\title{
Comparative study of different Portuguese samples of propolis: Pollinic, sensorial, physicochemical, microbiological characterization and antibacterial activity
}

\author{
Luís G. Dias ${ }^{\mathrm{a}, \mathrm{c}}$, Ana Paula Pereira ${ }^{\mathrm{c}, \mathrm{d}}$, Leticia M. Estevinho ${ }^{\mathrm{b}, \mathrm{c}, *}$

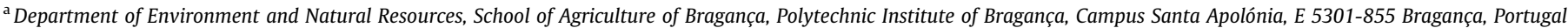 \\ ${ }^{\mathrm{b}}$ Department of Biology and Biotechnology, School of Agriculture of Bragança, Polytechnic Institute of Bragança, Campus Santa Apolónia, E 5301-855 Bragança, Portugal \\ ${ }^{\mathrm{C}}$ CIMO, Centro de Investigação de Montanha, School of Agriculture of Bragança, Polytechnic Institute of Bragança, Campus Santa Apolónia, E 5301-855 Bragança, Portugal \\ ${ }^{\mathrm{d}}$ IBB - Institute for Biotechnology and Bioengineering, Centre of Genomics and Biotechnology, University of Trás-os-Montes e Alto Douro, E 5001-801 Vila Real, Portugal
}

\section{A R T I C L E I N F O}

\section{Article history:}

Received 28 July 2012

Accepted 29 August 2012

Available online 5 September 2012

\section{Keywords:}

Antimicrobial

Microbiological quality

Physicochemical characterization

Propolis

Sensorial analysis

\begin{abstract}
A B S T R A C T
The aim of this work was to study four propolis samples from Trás-os-Montes region of Portugal. The propolis samples' color was different, which pollen analysis showed to be due to different botanical sources: Populus sp., Pinus sp., Quercus sp. and Castanea sativa. The data from physicochemical analysis (moisture, soluble and insoluble solids content, $\mathrm{pH}$, conductivity, ash content, wax, total phenolics and flavonoids content) was treated using multivariate statistical tools as cluster heat map, principal components analysis and linear discriminant analysis with the purpose of classifying the sample accordingly to the botanical/geographical origin. The discriminant analysis was applied with stepwise to select the variables that most contribute to sample identification accordingly to pollinic profile. The cross-validation technique was applied, using the leave-one-out procedure, which showed good prediction capabilities of the samples. Microbiologically, the commercial quality was satisfactory, since the samples didn't contain deterioration or pathogenic microorganisms. All the samples studied presented antimicrobial activity against Methicillin-resistant Staphylococcus aureus, in a dose dependent way. The antimicrobial activity was strictly related to the physicochemical composition. This work will allow connecting a particular chemical propolis type to a specific type of biological activity, what is essential for the use in therapeutic applications.
\end{abstract}

(c) 2012 Elsevier Ltd. All rights reserved.

\section{Introduction}

Propolis is a substance produced by bees (Apis mellifera L.) from harvested exudates of plant which are mixed with the salivary enzyme $\beta$-glucosidase. Bees use propolis in their combs as protection, to repair damage, to build aseptic locals and as a thermal insulator (Cardoso et al., 2011). Many studies have reported the efficiency of this product in medical treatments, both human and animal (Pastor et al., 2010; Carvalho et al., 2011). However, these studies have focused mainly the bioactive compounds' analysis and performed clinical assays, in order to ascertain the properties of this beehive product. These biological properties include antioxidant (Krol et al., 1990), anti-inflammatory (Paulino et al., 2008), anti-hepatotoxic (Banskota et al., 2001), anti-tumoral (Valente et al., 2011), anti-HIV-1 (Gekker et al., 2005) and cario-

\footnotetext{
* Corresponding author at: Department of Biology and Biotechnology, School of Agriculture of Bragança, Polytechnic Institute of Bragança, Campus Santa Apolónia, E 5301-855 Bragança, Portugal. Tel.: +351 273 303342; fax: +351 273325405

E-mail address: leticia@ipb.pt (L.M. Estevinho).
}

static (Libério et al., 2009). The antimicrobial activity of propolis against a wide range of bacteria, fungi and viruses has been investigated lately. These studies have reported that Staphylococcus aureus is one of the bacterial species that appears to be susceptible to propolis (Kilic et al., 2005). Indeed, the growing number of resistant pathogens is a reminder that the clock is ticking on the lifetime of the usefulness of current antibiotics. In this context, the research on natural products, such as propolis, plays a key role.

It is important to remember that the properties of this beehive product are related with its chemical composition (Silva et al., 2012). The chemical composition of propolis is highly variable mainly due to the variability of plant species growing around the hive, from which the bees collect the exudates (Bankova et al., 2000). According to Kumazawa et al. (2004), in samples from Brazil terpenoids and prenylated derivatives of $p$-coumaric acids predominated whilst the samples from China and Europe mostly contained phenolic acid esters and flavonoids. Bankova et al. (2000) reported that more than 300 different compounds can be found in propolis, being the most important: aliphatic acids, esters, aromatic acids, fatty acids, carbohydrates, aldehydes, amino acids, ketones, chalcones, dihydrochalcones, terpenoids, 
vitamins and inorganic substances. This is the reason why it is very important to study the composition of propolis from different regions.

In addition, in comparison to other countries, like Argentina, China, Australia and Bulgaria, Portugal is a small producer of propolis, being its production greatly confined to artisans. Propolis from Portugal has only recently begun to be studied; therefore, relatively little is known about its chemical composition, botanical origins, and biological properties. Portuguese propolis is currently being commercialized by less than $50 €$ per kilogram, whereas the product from other countries costs about $150 €$ per kilogram (Pereira et al., 2002). However, in order to economically value this product and to make it accepted officially into the mainstream of the health system, it's essential to ensure the chemical standardization, concerning its quality and safety (Bankova, 2005).

The present study was conducted in order to determine the chemical composition, to assess the safety, quality and sensorial characteristics of four samples of Portuguese propolis, obtained in locals with different predominant vegetation. The antimicrobial activity against methicillin-resistant S. aureus (MRSA), isolated from different biological fluids, was also assessed. In this context, the scientific research will act like a vector of the development of the national economy, since this study will help to certify the quality and the composition of propolis.

\section{Material and methods}

\subsection{Chemicals and reagents}

Ethanol $\left(\mathrm{CH}_{3} \mathrm{CH}_{2} \mathrm{OH}\right)$ was supplied by Pronolab (Lisbon, Portugal). The FolinCiocalteu reagent, chloroform $\left(\mathrm{CHCl}_{3}\right)$, sodium carbonate $\left(\mathrm{Na}_{2} \mathrm{CO}_{3}\right)$, gentaminice and fluconazol were obtained from Merck (Darmstadt, Germany). Gallic acid and catechin were purchased from Sigma (St. Louis, MO, USA). The culture mediums were purchased from Himedia (India). The TTC solution (2,3,5-triphenyl-2H-tetrazolium chloride) was supplied by Fluka (Buchs, Switzerland). All other chemicals were obtained from Sigma Chemical Co. (St. Louis, MO, USA). All the reagents were of analytical grade purity. The culture mediums were bought from Himedia (India). High purity water $(18 \mathrm{M} \Omega \mathrm{cm}$ ) was obtained from a Milli-Q purification system (Millipore, Bedford, MA, USA).

\subsection{Propolis samples}

Propolis samples were collected by beekeepers between August and September of 2011 from four places of the Trás-os-Montes region in the extreme northeast corner of Portugal: Mirandela $\left(41^{\circ} 29^{\prime} \mathrm{N} 7^{\circ} 11^{\prime} \mathrm{W}\right)$, Mogadouro $\left(41^{\circ} 20^{\prime} \mathrm{N} 6^{\circ} 43^{\prime} \mathrm{W}\right)$, Nogueira $\left(41^{\circ} 46^{\prime} \mathrm{N} 6^{\circ} 49^{\prime} \mathrm{W}\right)$ and Vinhais $\left(41^{\circ} 49^{\prime} \mathrm{N}, 7^{\circ} 0^{\prime} \mathrm{W}\right)$. Considering the geographic differences, the Trás-os-Montes region can be grouped into two areas: the "Terra Fria Transmontana" (Cold Lands) is the northern area, with the higher altitudes, where the landscape is dominated by gentler slopes in the plateau, and the "Terra Quente Transmontana" (Hot Lands), the southern areas, marked by the valleys of the Douro River These two areas have significant climate differences, which gives a wide diversity of landscapes. The locals Vinhais and Nogueira are in Cold Lands separated by $20 \mathrm{~km}$. Mirandela and Mogadouro are locals separated by $70 \mathrm{~km}$ in the Hot Lands.

It were collected three samples per location $(n=12)$ and for each sample it were performed three replicates. They were obtained after the honey extraction by scratching the hive walls and frames. Each sample was inspected in order to find rests of bees, wood, plant, pupa of moth, among others. The major visible impurities were removed from the samples. Each sample was weighed and frozen at $-20^{\circ} \mathrm{C}$ until analysis.

\subsection{Sensorial analysis}

The propolis samples were submitted to sensorial analysis as recommended by the Brazilian Ministry of Agriculture (Instrução Normativa n 3, de 19 de Janeiro de 2001), since in Portugal there is no legislation concerning propolis. Panel members $(n=20)$ aged between 18 and 58 years were selected among undergraduate and graduate students, as well as employees and lecturers belonging to the School staff. The parameters analyzed were the color, aroma, consistency and granulometry.

\subsection{Pollinic analysis}

The pollen morphology identification is very important since it allows characterizing the geographical regions where propolis was obtained, as well as the habitat of forest, fields and crops. The pollen analysis was executed by the methodology described by Barth (1989). The pollen attainment was initiated by mixing of $0.5 \mathrm{~g}$ of propolis with $15 \mathrm{~mL}$ of absolute alcohol during $24 \mathrm{~h}$. The mixture obtained after centrifugation was boiled on $\mathrm{KOH} 10 \%$ for 2 min in water-bath. The sediment was washed in distilled water, filtered, and kept in glacial acetic acid during a night. Then acetolise of pollen sediments was carried out in a mixture 9:1 of acetic acid and anhydride sulphuric acid, in water-bath until reaching the temperature of $80^{\circ} \mathrm{C}$ for about $3 \mathrm{~min}$. After careful sediment washing with water and glycerinate-water, the sediment was mounted in gelatine-glycerinate, with or without courante (fuchsine basic).

\subsection{Physicochemical analysis}

All the tests were performed in triplicate.

\subsubsection{Moisture}

The determination of moisture was ascertained by the standard method (AOAC Official Method 934.01). Five grams of propolis were dried in a mechanical convection oven at $105^{\circ}$ for $1 \mathrm{~h}$. After this time, it was removed and let cool to room temperature and weight back. The procedure was repeated just to stabilize the weigh. The water content was determined using the equation, in which A1 = weigh of sample; $A 2$ = weigh of sample dried:

Moisture $(\%)=\frac{100 \times[\mathrm{A} 1-\mathrm{A} 2]}{\mathrm{A} 1}$

\subsubsection{Soluble and insoluble solids in ethanol}

According to AOAC (2005), to one gram of each propolis sample, $250 \mathrm{ml}$ of ethanol was added. The mixture was shacked in an automatic mixing machine and after $30 \mathrm{~min}$ the solution was filtered and the insoluble solids weighed. The soluble solids (SS) were determined by the difference between sample weigh (SW) and insoluble weigh (IW). The result was expressed in percentage, by applying the equation for soluble solids:

SS $(\%)=\frac{S W-I W}{S W} \times 100$

For insoluble solids:

IS $(\%)=\frac{\mathrm{IW}}{\mathrm{SW}} \times 100$

\subsection{3. $\mathrm{pH}$}

Propolis $\mathrm{pH}$ was measured with a combined $\mathrm{pH}$ glass electrode connected to $\mathrm{pH}$-meter Basic 20, in a solution prepared with $10 \mathrm{~g}$ of propolis in $75 \mathrm{~mL}$ of methanol (NP 1309/1976), using methanol as control. Calibration was performed with three standard buffer solutions.

\subsubsection{Conductivity}

Electrical conductivity of a propolis solution at $20 \%(\mathrm{w} / \mathrm{v})$ (dry matter basis) in methanol was measured at $20^{\circ} \mathrm{C}$ in a Crison 522 conductimeter. Results were expressed as milliSiemens per centimeter $(\mathrm{mS} / \mathrm{cm})$.

\subsubsection{Ash content}

The method used in the experiments to determine the mineral content and other inorganic matter in propolis consisted of the desiccation of an amount of $5 \mathrm{~g}$, for each propolis sample, in a platinum dish (AOAC Official Method 920.181). To do so, they were kept in the thermostat at $80^{\circ} \mathrm{C}$ for $4 \mathrm{~h}$, after which the samples underwent calcination at $550^{\circ} \mathrm{C}$, in an electric laboratory furnace SNOL 8.2/1100-1 (AB "Umega", Utena, Lithuania) to constant mass. Total ash contents, expressed as the percentage of residue left after dry oxidation by weight (\%), was calculated from the following equation, where $m_{1}$ is the mass of dish and ash, $m_{2}$ the mass of platinum dish prior to calcination and $m_{0}$ is the mass of the propolis taken:

Ash $(\%)=\left[\frac{m 1-m 2}{m 0}\right] \times 100$

\subsubsection{Wax}

It was weighed $250 \mathrm{~g}$ of each sample and added $750 \mathrm{ml}$ of methanol. The mixture was placed in a freezer over-night $\left(-20^{\circ} \mathrm{C}\right)$. Afterwards, the solution was filtered to obtain the wax. The wax was expressed in percentage (W\%) using the sample weigh (SW) and the wax weigh (WW). The equation used was:

$\mathrm{W}(\%)=\frac{\mathrm{WW}}{\mathrm{SW}} \times 100$

2.5.7. Determination of the bioactive compounds

2.5.7.1. Extraction. Prior to the extraction, the propolis was grounded and homogenized. The samples were extracted with $80 \%$ of ethanol/water $(1 / 10, v / v)$ at $70{ }^{\circ} \mathrm{C}$ for $1 \mathrm{~h}$. The resulting mixtures were filtered, and the residues were re-extracted in the same conditions. After the second extraction, the filtrated solutions were combined, concentrated and frozen at $-20^{\circ} \mathrm{C}$ (Silva et al., 2012). 
2.5.7.2. Determination of the total phenolics. The total phenolic content in the extracts was evaluated indirectly by relating the reducing capacity of propolis and Gallic acid standard compound using the Foulin-Ciocalteu method as described by Moreira et al. (2008). Briefly, a dilute solution of each propolis in EtOH (EtOHpropolis; $500 \mu \mathrm{L}$ of $1: 10 \mathrm{~g} / \mathrm{mL}$ ) was mixed with $500 \mu \mathrm{L}$ of Folin-Ciocalteu reagent and $500 \mu \mathrm{L}$ of $\mathrm{Na}_{2} \mathrm{CO}_{3}(10 \% \mathrm{w} / \mathrm{v})$. After incubation in dark at room temperature for $1 \mathrm{~h}$, the absorbance of the reaction mixture at $700 \mathrm{~nm}$ was determined against the blank (the same mixture without the EtOH-propolis) using a Unicam Helios Alpha UV-visible spectrometer (Thermo Spectronic, Cambridge, UK). Galic Acid standard solutions $(0.01-0.08 \mathrm{mM})$ were used for constructing the calibration curve $\left(y=2.3727 x+0.0022 ; R^{2}=0.9998\right)$. Total phenols content were expressed as $\mathrm{mg}$ of Galic Acid equivalents per $g$ of propolis (GAEs).

2.5.7.3. Determination of flavonoids. To determine the flavonoids it was used the aluminum chloride method. In briefly, EtOH-propolis $(250 \mu \mathrm{L})$ was mixed with $1.25 \mathrm{~mL}$ of distilled $\mathrm{H}_{2} \mathrm{O}$ and $75 \mu \mathrm{L}$ of a $5 \% \mathrm{NaNO}_{2}$ solution. After $5 \mathrm{~min}, 150 \mu \mathrm{L}$ of a $10 \% \mathrm{AlCl}_{3} \cdot \mathrm{H}_{2} \mathrm{O}$ solution was added. After $6 \mathrm{~min}, 500 \mu \mathrm{L}$ of $1 \mathrm{M} \mathrm{NaOH}$ and $275 \mu \mathrm{L}$ of distilled $\mathrm{H}_{2} \mathrm{O}$ were added to the mixture and vortexed. The intensity of pink color of the reaction mixture at $510 \mathrm{~nm}$ is determined against the blank (the same mixture without the EtOH-propolis). Catechin standard solutions $(0.022-0.34 \mathrm{mM}$ ) were used for constructing the calibration curve $(y=0.9689 x-0.0092$; $R^{2}=0.9987$ ). Total flavonoids content were expressed as $\mathrm{mg}$ of catechin equivalents per $g$ of propolis (CAEs)

\subsection{Microbiological determinations}

It were researched the commercial quality parameters: mesophilic microorganisms, yeasts and moulds, indicators of sanitary quality: fecal coliforms and Escherichia coli, indicators of safety: sulphite reducing clostridium spores and Salmonella. All microbial tests were performed in triplicate.

\subsubsection{Sample preparation}

Prior to the microbiological assays, $10 \mathrm{~g}$ of each propolis samples were aseptically taken and homogenized using a pre-sterilized Stomacher Lab-Blender (Seward type 400 , London, UK) for $3 \mathrm{~min}$ with $90 \mathrm{~mL}$ of pre-chilled $\left(4 \pm 0.5^{\circ} \mathrm{C}\right)$ sterile peptone-physiological saline solution $(0.1 \%$ neutral peptone $+0.85 \% \mathrm{NaCl}$ in sterile deionized $\mathrm{H}_{2} \mathrm{O}, \mathrm{pH}=7.0 \pm 0.05$ ). Decimal serial dilutions were prepared from this homogenate in the same chilled sterile diluents $(1: 10(\mathrm{w} / \mathrm{w}))$.

\subsubsection{Enumeration of the total mesophilic microorganisms}

The aerobic mesophilic microorganisms were counted by incorporation of $1 \mathrm{~mL}$ of each dilution into standard Plate Count Agar (PCA), as recommended in NP-3788 (2002) - Portuguese Legislation. Microbial counts were expressed as colony-forming units per gram of propolis $(\mathrm{cfu} / \mathrm{g})$.

\subsubsection{Enumeration of yeast and moulds}

Moulds and yeasts enumeration was made on DG18 (Himedia) and incubated at $25^{\circ} \mathrm{C}$ for 5 days (ISO 21527-2, 2008). Microbial counts were expressed as colonyforming units per gram of propolis $(\mathrm{cfu} / \mathrm{g})$.

\subsubsection{Enumeration of total coliforms and Escherichia coli}

Enumeration of coliforms and Escherichia coli was done using the SimPlate CEcCI method (AOAC ${ }^{\circledR}$ Official Method 2005.03) with multiple test medium (BioControl System), according to the manufacturer's instructions and procedures of Feldsine et al. (2005). One $\mathrm{ml}$ from the basic dilution was placed in the centre of the SimPlate plating device, and $9 \mathrm{ml}$ of a mixed nutrient agar with blue color was added at the same spot. The SimPlate was rotated in order to disperse the sample and remove air-bubbles. The SimPlates were stacked and stored at $37 \pm 1{ }^{\circ} \mathrm{C}$ for $24-28 \mathrm{~h}$. Wells were counted positive for total coliforms on the basis of the color change and counted positive for $E$. coli on the basis of color change and fluorescence under UV light. The coliform and E. coli populations were determined on the basis of the number of positive wells correlated with the SimPlate conversion table, which generated a most probable number (MPN) per gram of sample.

\subsubsection{Determination of sulphite reducing clostridium spores}

For sulphite-reducing clostridia counting, aliquots of $10,5,1$ and $0.1 \mathrm{~mL}$ of the initial suspension were added to an empty tube, thermally treated at $80^{\circ} \mathrm{C}$ for 15 min and covered with Differential Reinforced Clostridial Broth (DRCM) (Himedia), and incubated at $37^{\circ} \mathrm{C}$ for 5 days. At the end, it were counted the black colonies. The results are expressed as presence of Sulphite-reducing clostridia in $0.01 \mathrm{~g}$ (ISO 15213, 2003). Results were expressed as most probable numbers of Sulphitereducing Clostridium spores per gram of bee pollen (MPN/g).

\subsubsection{Determination of S. aureus}

The detection was performed according to the protocol of NP 4400-1 (2002). Following the existent legislation, serial dilutions of the sample were inoculated in Baird-Parker Broth with Egg Yolk Tellurite and Sulfadimidine Solution (Himedia) during $24 \mathrm{~h}\left(37^{\circ} \mathrm{C}\right)$. After, it were selected 3-5 characteristic colonies, in order to testify the presence of coagulase and catalase. Microbial counts were expressed as colony-forming units per gram of propolis ( $\mathrm{cfu} / \mathrm{g}$ ).

\subsubsection{Detection of Salmonella $\mathrm{sp}$.}

The detection of Salmonella sp. in the samples was carried out using the immunodifusion 1-2 test, which is a patented single-use test for Salmonella used by analysts worldwide and recognized as the $A O A C^{\circledR}$ Official Method 989.13. Rapid and reliable results are obtained $16-20 \mathrm{~h}$ after pre-enrichment in buffered peptone water. The results are interpreted visually by observing the development of an immunoband, a characteristic immobilization pattern of cells.

\subsection{Antimicrobial activity assays}

The Methicillin-resistant S. aureus used in the antimicrobial activity assays were isolated from biological fluids (in the Hospital Centre) and identified in the Microbiology Laboratory of Escola Superior Agrária de Bragança. Microorganism A was isolated from vaginal exudates, B from urine, $C$ from pus, D from expectoration and $\mathrm{E}$ from blood culture. Microorganism $\mathrm{F}$ is a reference culture (ATCC $6538^{\mathrm{TM}}$ ), obtained from the authorized distributor of ATCC (LGC Standards S.L.U., Barcelona). A broth microdilution bioassay in sterile 96-well plates (Sarker et al., 2007) was used to evaluate the growth-inhibiting activity of the test materials toward the organisms. In brief, $100 \mu \mathrm{L}$ of each test material in MHB medium containing $2.5 \% \mathrm{di}-$ methyl sulfoxide (DMSO) were added to wells of the first rows of plates, and $50 \mu \mathrm{L}$ MHB medium was added to remain wells. Serial twofold dilutions of the test materials were prepared. The bacterial suspension $(50 \mu \mathrm{L})$ containing $1 \times 10^{5}$. cfu $\mathrm{mL}^{-1}$ of each test organism was added to all the wells except those used for backgrounds and blanks that included test samples and DMSO-containing medium only, respectively. Then, $50 \mu \mathrm{L}$ of medium was added into the background and blank wells. Gentamicin served as positive control.

Antimicrobial activity was detected by adding $20 \mu \mathrm{L}$ of $0.5 \%$ TTC solution. Minimum inhibitory concentration (MIC) end-points were interpreted as the lowest sample concentration that remained unstained by TTC (indicating no growth) or the first dilution that changed to slightly purple (equivalent to prominent growth inhibition). The assays were repeated three times.

\subsection{Statistical analysis}

Results are shown as mean values and standard deviation. Correlation coefficients among the different variables were computed using the Pearson correlation coefficient. Cluster Heat map was done with software R ( R Development Core Team, 2012). The results and graphs from the application of principal component analysis and linear discriminant analysis to the physicochemical parameters were obtained using the software JMP Pro 10.0.0. In the microbiological determinations and antimicrobial activity, the differences were analyzed using one-way analysis of variance (ANOVA) followed by Tukey's HSD. The p values less than or equal to 0.05 were evaluated as statistically significant. This treatment was carried out using SPSS version 18 (IBM Software).

\section{Results and discussion}

\subsection{Sensorial analysis}

The results of the sensorial analysis (color, aroma, consistency and granulometry) are presented in Table 1 . All propolis samples showed heterogeneity in their constitution. The color differences between samples (the samples from Cold Lands are darker) showed that the main vegetable origin of propolis formulation is different, which is supported by each sample pollinic profile. Indeed, Fontana et al. (2004) claimed that the contribution of the flora to propolis plus the wax content may explain the physical properties of the product. The balsamic aroma is present in three samples, except in Mirandela sample, which has a resinous aroma (Populus sp. is the main pollen). Propolis from Mirandela and

Table 1

Sensorial characteristics of propolis samples.

\begin{tabular}{lllll}
\hline Sample region & Color & Aroma & Consistency & Granulometry \\
\hline Mirandela & Green & Resinous & Manageable & Heterogeneous \\
Mogadouro & Red-yellow & Balsamic & Hard & Heterogeneous \\
Nogueira & Red-Brown & Balsamic & Manageable & Heterogeneous \\
Vinhais & Brown & Balsamic & Hard & Heterogeneous \\
\hline
\end{tabular}


Nogueira have manageable consistency (Populus sp. and Quercus sp. as main pollen, respectively). The samples from Mogadouro and Vinhais presented hard consistency (Pinus sp. and Castanea sativa as main pollen, respectively).

\subsection{Pollinic analysis}

The three most predominant pollens and the percentage of number of pollen grains counted in each sample are shown in Table 2 . The total percentage of the three main pollens, in each sample, is higher than $82 \%$. In the four samples, the most predominant pollen has percentages between $46.5 \pm 6.6 \%$ and $58.0 \pm 7.1 \%$, the second predominant pollen in counts are between $17.5 \pm 2.3 \%$ and $22.0 \pm 4.0 \%$ and the third predominant pollen, lower than $14 \%$. The pollen profile considering the main three pollens is described by five types of pollen: C. sativa, Erica sp., Pinus sp., Populus sp., Prunus sp. and Quercus sp. Considering the main pollen (counts higher than $46.5 \%$ ), the four propolis samples have different vegetation origin: Populus sp. (Mirandela sample), Pinus sp. (Mogadouro sample), Quercus sp. (Nogueira sample) and C. sativa (Vinhais sample). All the samples had great percentages of Populus sp. This is in agreement with the reported by Falcão et al. (2010), who analyzed samples from the temperate zones, among which Portugal.

\subsection{Chemical composition}

In the existent studies on the chemical composition of European propolis it have only been determined and identified the phenolic compounds and flavonoids (Popova et al., 2004; Moreira et al., 2008; Falcão et al., 2010; Salonem et al., 2012; Silva et al., 2012). However, parameters like moisture, total content in insoluble substances and soluble substances, $\mathrm{pH}$, conductivity, ash and wax have never been tested. The results obtained for the physicochemical parameters are shown in Table 3. Globally, the precision of the triplicate assays reflects the samples heterogeneity referred previously. The moisture results varied between $3.4 \pm 0.2 \%$ and $5.4 \pm 0.4 \%$. High moisture content was obtained for Nogueira and Mogadouro propolis samples and the lower value for the Vinhais sample. These results lead us to infer that the consistency of propolis, referred in sensory analysis, was not directly related to the humidity of the sample. Our values were slightly superior to the ones obtained by Bonvehi et al. (1994), who studied propolis from Uruguay and China.

Total insoluble and soluble substances results showed that, in the triplicate assays, the precision was reasonable since the relative standard error percentages are lower than 7.0\%. Mirandela sample has the higher content in soluble substances (71.1 $\pm 2.2 \%$ ), Mogadouro and Nogueira samples have similar results (both have values near $66 \%)$ and Vinhais sample the lowest value $(60.7 \pm 5.1 \%)$. The sum of these two parameters showed to be nearby the expected value, $100 \%$, except in one assay of Nogueira sample where the difference has a high value (this sample presented high variability in total insoluble substances parameter, with relative standard error percentage of $7.0 \%$ ), maybe due to sample higher heterogeneity within this assay.
The $\mathrm{pH}$ values of the propolis samples are in the range of $4.7 \pm 0.1$ to $5.3 \pm 0.2$. Mirandela and Vinhais samples gave similar and higher levels of $\mathrm{pH}$ (5.3), while the lowest $\mathrm{pH}$ value (4.7) was obtained in the Nogueira sample. Our results are in agreement with the claimed by Sousa et al. (2007). Tikhonov et al. (1978) found slightly higher values of $\mathrm{pH}$, being the mean value equal to $6.20 \pm 0.15$.

The conductivity of propolis was analyzed and results were similar and higher in the samples from Nogueira and Mogadouro $(2.2 \pm 0.2$ and $2.4 \pm 0.3 \mathrm{mS} / \mathrm{cm}$, respectively) and the lower result (half of the value of the other sample obtained in the same geographic area) was obtained in the sample of Mirandela $(1.2 \pm 0.1 \mathrm{mS} / \mathrm{cm})$. These results cannot be explained by the composition in minerals of the samples (ash content), since the amounts of ash showed a different trend from that obtained for conductivity. In decreasing order of ash content, the samples are: Vinhais $(2.2 \pm 0.08 \%)$, Nogueira $(2.0 \pm 0.3 \%)$, Mirandela $(1.9 \pm 0.1 \%)$ and Mogadouro (1.6 $\pm 0.02 \%)$. The order presented shows that this parameter allows to separate the samples obtained in the Cold Lands from the ones of the Hot Lands in the region of Trás-os-Montes. The content in ashes found in this study was similar to the reported in Chinese propolis (Bonvehi et al., 1994).

The quantity of wax is very different between the samples. The results, in mass percentage, varied in the range of $4.8 \pm 0.4 \%$ to $16.0 \pm 2.1 \%$. These data are coherent with the reported in the literature, since the maximum wax content found was $15 \mathrm{~g} / 100 \mathrm{~g}$ (Silva et al., 2012). According to Negri et al. (1998), the composition of propolis wax is similar to that of comb wax, which suggests that propolis waxes are secreted by bees, rather than originating from plants.

The total quantity of polyphenols and flavonoids in propolis are important parameters to evaluate the quality and biological potentialities of the product (Moreira et al., 2008). The specific phenolic composition of propolis is extremely dependent on the plants found around the hive, as well on the geographic and climatic characteristics of the place (Bankova et al., 2000). The results show differences among samples that are in accordance with their local of origin. The samples obtained in the Cold Lands (Nogueira and Vinhais) have higher content of phenolic compounds and flavonoids compounds (mass percentages, $>23.0 \pm 2.0 \%$ and $>9.5 \pm 2.0 \%$, respectively) than the samples of the Hot Lands (Mirandela and Mogadouro samples), whose quantities are either less than or equal to half of that obtained in previous samples. Our results demonstrate that these bioactive compounds are important constituents of the Portuguese propolis samples. In the same context, Kujumgiev et al. (1999) found flavanoids and phenolic acid esters as main constituents in Bulgarian samples. The amount of polyphenols and flavonoids obtained in this study is in agreement with the reported in the literature. The content of phenolic compounds obtained by Choi et al. (2006) in Korean propolis ranged between $12.0 \%$ and $21.2 \%$. Silva et al. (2012) found values between $8.7 \%$ and $27.7 \%$ for the polyphenols and between $2.5 \%$ and $14.2 \%$ for flavonoids.

To verify how these results allow classifying and differentiating the four samples, it is presented in Fig. 1 the graph cluster Heat Map that displays the hierarchical cluster structure, simulta-

Table 2

Pollen profile of the propolis samples.

\begin{tabular}{|c|c|c|c|c|c|c|}
\hline \multirow[t]{2}{*}{ Sample region } & \multicolumn{6}{|l|}{ Pollen type } \\
\hline & Castanea sativa & Erica sp. & Pinus sp. & Populus sp. & Prunus sp. & Quercus sp. \\
\hline Mirandela & & & $11.00 \pm 2.80$ & $58.00 \pm 7.10$ & $17.50 \pm 2.30$ & \\
\hline Mogadouro & $13.50 \pm 1.80$ & & $46.50 \pm 6.60$ & $22.00 \pm 4.00$ & & \\
\hline Nogueira & $20.00 \pm 2.00$ & & & $9.00 \pm 1.80$ & & $56.50 \pm 6.80$ \\
\hline Vinhais & $49.50 \pm 5.20$ & $20.50 \pm 3.90$ & & $14.00 \pm 2.30$ & & \\
\hline
\end{tabular}


Table 3

Physicochemical characteristics of the samples (average \pm standard deviation).

\begin{tabular}{|c|c|c|c|c|c|c|c|c|c|}
\hline $\begin{array}{l}\text { Sample } \\
\text { region }\end{array}$ & $\begin{array}{l}\text { Moisture } \\
(\%)\end{array}$ & $\begin{array}{l}\text { Insoluble } \\
\text { substances (\%) }\end{array}$ & $\begin{array}{l}\text { Soluble } \\
\text { substances (\%) }\end{array}$ & $\mathrm{pH}$ & $\begin{array}{l}\text { Conductivity } \\
(\mathrm{mS} / \mathrm{cm})\end{array}$ & Ash (\%) & $\begin{array}{l}\text { Waxes } \\
(\%)\end{array}$ & $\begin{array}{l}\text { Phenolic } \\
\text { compounds (\%) }\end{array}$ & $\begin{array}{l}\text { Flavonoid } \\
\text { compounds (\%) }\end{array}$ \\
\hline Mirandela & $3.4 \pm 0.2$ & $27.0 \pm 1.0$ & $71.1 \pm 2.2$ & $5.3 \pm 0.2$ & $1.2 \pm 0.1$ & $1.9 \pm 0.1$ & $7.6 \pm 0.7$ & $11.1 \pm 1.3$ & $3.1 \pm 0.3$ \\
\hline Mogadouro & $5.4 \pm 0.4$ & $40.2 \pm 0.9$ & $66.0 \pm 4.1$ & $5.2 \pm 0.2$ & $2.4 \pm 0.3$ & $1.6 \pm 0.02$ & $4.8 \pm 0.4$ & $17.2 \pm 6.9$ & $4.0 \pm 1.0$ \\
\hline Nogueira & $5.3 \pm 0.4$ & $45.0 \pm 7.0$ & $66.3 \pm 3.2$ & $4.7 \pm 0.1$ & $2.2 \pm 0.2$ & $2.0 \pm 0.3$ & $12.2 \pm 0.9$ & $28.0 \pm 2.0$ & $12.0 \pm 2.0$ \\
\hline Vinhais & $3.7 \pm 0.2$ & $45.1 \pm 2.0$ & $60.7 \pm 5.1$ & $5.3 \pm 0.1$ & $1.7 \pm 0.1$ & $2.2 \pm 0.08$ & $16.0 \pm 2.1$ & $23.0 \pm 2.0$ & $9.5 \pm 2.0$ \\
\hline
\end{tabular}

neously, of the propolis samples and physicochemical variables (rows and columns in the data matrix, respectively). The data matrix individual values are represented as colors being the larger values represented by small dark gray or black squares and smaller values by lighter squares. To avoid the variables dimension of being a factor of importance in the cluster analysis, the variables (columns) were normalized to the same dynamic range ( $\mathrm{Z}$ dimension).

The Fig. 1 shows the samples divided in two groups accordingly to their areas of origin: in the Hot Lands propolis samples there is a separation between the two samples accordingly to its local of origin, as opposed to samples of Cold Lands, where the Vinhais sample was grouped together with Nogueira sample.

The Heat Map graph, for the physico-chemical variables shows three groups: the first consists of the variables of total content of soluble and insoluble substances in the samples; the second group consists of all other variables except the variable of total amount of phenolic compounds, which is the only variable in group 3 . In the second group, the presence of the variable total amount of flavonoid compounds was not expected since the variable of flavonoid compounds have a high correlation with the variable of the phenolic compound (Pearson coefficient correlation, $R=0.94$ ).

Another unsupervised multivariate method that can show the natural data pattern is principal component analysis (PCA). After centralize and standardize the data matrix for each attribute, this method is just linear combinations of the original variables. Globally, the first two principal component variables (two dimensions which account for the maximum amount of variance) explain $77.2 \%$ of the data variability in the physicochemical variables and the extracted information clearly allows classifying propolis samples accordingly to their local geographic of origin.

Fig. 2 shows the projection of samples (the first plot) and the loadings of the original variables (the second plot) on the first two principal components. The first plot (score plot) shows that the first principal component allows separating the samples of different areas of origin: for higher values of PC1 are present samples of Nogueira and Vinhais (Cold Lands) and for negative values, samples of Mirandela and Mogadouro (Hot Lands). The second main

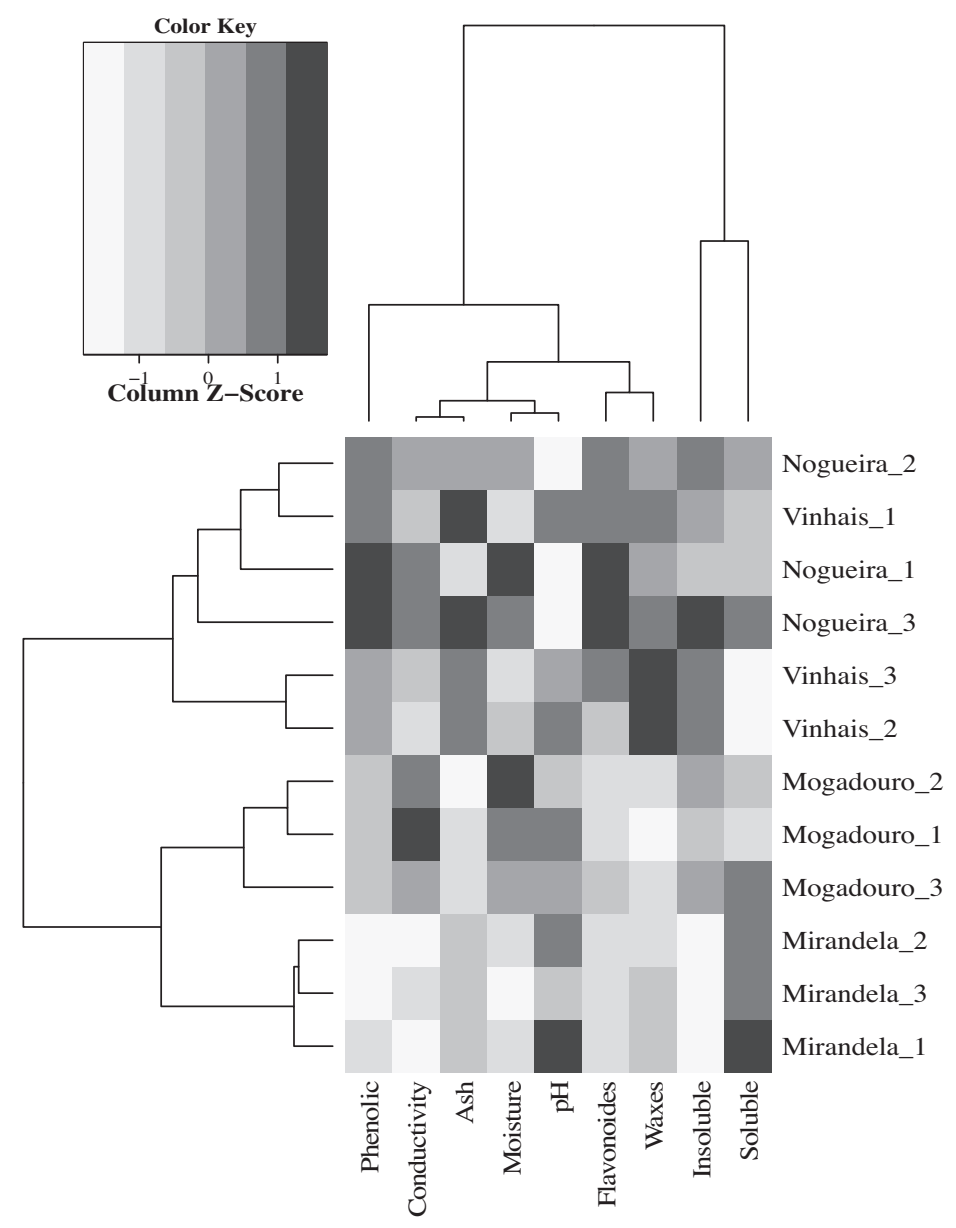

Fig. 1. Cluster Heat Map of the propolis samples and physicochemical parameters. 

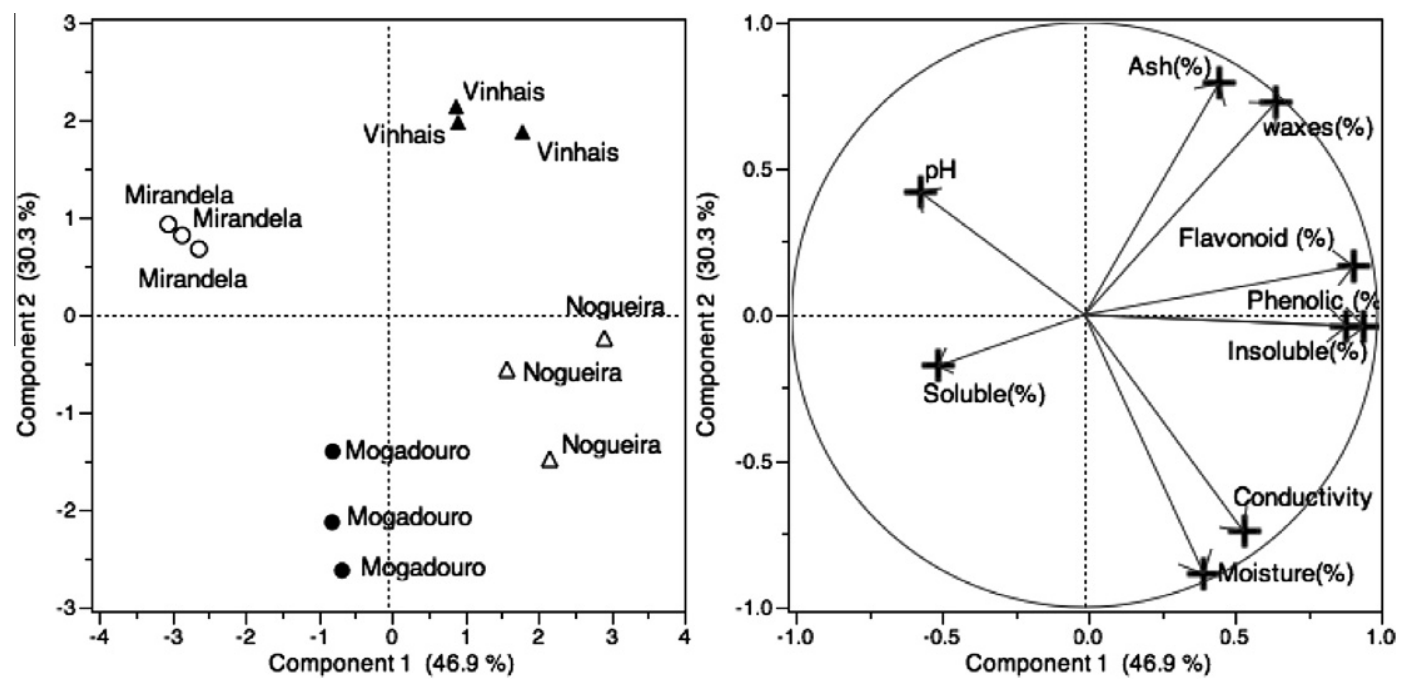

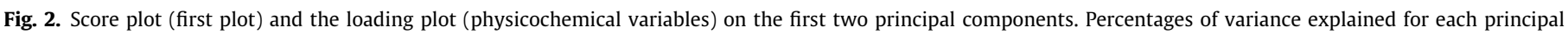
component are given in parentheses.

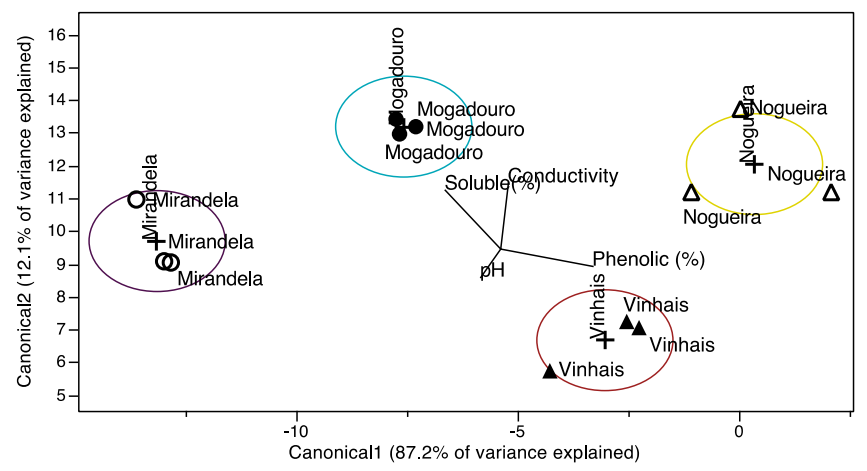

Fig. 3. Propolis samples LDA classification into four groups accordingly to their locals of origin. Percentages of variance explained for each discriminant function are given in parentheses.

component allows identifying each propolis sample accordingly to the local of origin.

The orientation of the physicochemical variables in the second plot show how they contribute in the first two principal components to separate samples. The arrow shows the direction towards where a variable contributes with high values in the principal components space. Considering the extrapolation of the same arrow (in the same direction) but in the reverse way, it is where the variable contributes with low values.

Highlighting only the high values, Fig. 3 shows that: samples from Hot Land show high values of $\mathrm{pH}$ and total amount of soluble substances; the sample of Mirandela has higher values over the sample Mogadouro, which has high values of moisture\% and conductivity values; for the two samples from the Cold Land it seems that the high values for variables Ash and waxes contribute to the separation of sample Vinhais (also with high $\mathrm{pH}$ ) while sample Nogueira seems to be differentiated from other samples due to the remaining variables, mainly to high values of phenolic and flavonoid compounds content. The variables that have nearby projections in the loading plot shows similar contribution in the principal components obtained, indicating a possible redundancy in the information provided by these variables.

To determine which physicochemical variables were the most important to classify the four samples of propolis in relation to their local of origin, it was used a supervised method of classification, the linear discriminant analysis (LDA) with stepwise (based on backward criterion with the probability ( $p$-value) of 0.15 for enter and remove variables).

All independent variables selected by the stepwise procedure of the discriminant analysis were statistically significant according to the Wilks' Lambda test $(p<0.001)$. The stepwise LDA resulted in a discriminant model with three discriminant functions, being only the first two significant ( $p<0.001$ for the Wilks' Lambda test). These two functions explained $99.3 \%$ of the variance of the experimental data (the first function explain $87.2 \%$ and the second, $12.1 \%)$. The model was based in four physicochemical variables: $\mathrm{pH}$, conductivity, soluble substances and phenolic compounds. The variables $\mathrm{pH}$ and total content in soluble substances remained important to distinguish samples of locals of Hot Land from those of Cold Land. From the remaining variables only two were selected - the conductivity and the amount of phenolic compounds - as being the most important for identifying the origin of propolis samples in Cold Land; high values of conductivity distinguish the Nogueira sample, as expected, from the Vinhais sample, which as high values of phenolic compounds.

Fig. 3 shows the graph of the first two functions obtained by linear discriminant analysis using stepwise to establish which physicochemical variables allow the identification/separation of the four samples of propolis. The model showed a very satisfactory classification performance allowing to correctly classifying $100 \%$ of propolis samples for the cross-validation technique, using the leaveone-out procedure.

These results are consistent with those obtained in principal component analysis in which the assessment of the variable loadings was done. The linear discriminant analysis proved to be advantageous because it allowed obtaining a mathematical model where the variables considered were selected, reducing the redundancy of information, and verify the model predictive ability by using leave-one-out procedure.

\subsection{Microbiological determinations}

The levels of microbial contamination of propolis are presented in Table 4. Studies about the microbiological contamination of this natural product have never been carried out. However, according to the Brazilian legislation the microbiological quality of propolis must be controlled (Instrução Normativa $n^{\circ} 3$, de 19 de Janeiro de 2001). 
Table 4

Microbiological analysis of the propolis samples.

\begin{tabular}{|c|c|c|c|c|c|c|c|}
\hline Sample & $\begin{array}{l}\text { Aerobic mesophiles (cfu } \\
\mathrm{g}^{-1} \text { ) }\end{array}$ & $\begin{array}{l}\text { Moulds and yeast } \\
\left(\mathrm{cfu}^{-1}\right)\end{array}$ & $\begin{array}{l}\text { Total coliforms } \\
\text { (ufc/g) }\end{array}$ & $\begin{array}{l}\text { Escherichia coli } \\
\text { (ufc/g) }\end{array}$ & $\begin{array}{l}\text { Sulphite-reducing } \\
\text { clostridia (in } 0.01 \mathrm{~g} \text { ) }\end{array}$ & $\begin{array}{l}\text { Salmonella } \\
\text { (in } 25 \mathrm{~g} \text { ) }\end{array}$ & $\begin{array}{l}\text { Staphylococcus } \\
\text { aureus (ufc/g) }\end{array}$ \\
\hline Mirandela & $106.67 \pm 23.09 \mathrm{~b}$ & $63.33 \pm 27.54 \mathrm{a}$ & $26.67 \pm 11.55 b$ & $<1 \mathrm{a}$ & Absent & Absent & Absent \\
\hline Mogadouro & $71666.70 \pm 51661.11 \mathrm{a}$ & $75.00 \pm 18.03 \mathrm{a}$ & $\begin{array}{l}113.33 \pm 30.55 \\
\mathrm{a}\end{array}$ & $16.67 \pm 5.77 \mathrm{a}$ & Absent & Absent & Absent \\
\hline Nogueira & $1096.67 \pm 430.16 b$ & $56.67 \pm 11.55 \mathrm{a}$ & $\begin{array}{l}103.34 \pm 28.86 \\
\mathrm{a}\end{array}$ & $<1 \mathrm{a}$ & Absent & Absent & Absent \\
\hline Vinhais & $7933.33 \pm 1792.57 b$ & $73.33 \pm 15.28 \mathrm{a}$ & $<1 \mathrm{~b}$ & $<1 \mathrm{a}$ & Absent & Absent & Absent \\
\hline
\end{tabular}

Results are given as the mean \pm standard deviation. The letter (a) represents that the honeys are not different by Tukey test with significance of $\alpha=0.05$.

The results obtained for the aerobic mesophiles were between $71666.70 \pm 51661.11 \mathrm{cfu} \mathrm{g}^{-1}$ and $106.67 \pm 23.09 \mathrm{cfu} \mathrm{g}^{-1}$ in the samples from Mogadouro and Mirandela, respectively. Significant differences were found between the samples from these origins. Concerning the moulds and yeasts, it were not found significant differences between the different propolis. The total coliforms were found in three of the samples, but in low number. For $E$. coli the obtained values were very small and statistically similar in all the analyzed products. All samples showed negative results for toxigenic species. The propolis with worse microbiology quality were the ones with higher moisture and $\mathrm{pH}$, as expected. These results are in agreement with the reported by Gomes et al. (2010) and Horner and Anagnostopoulos (1973). The microbiological quality of propolis is worse than the quality of honey and bee pollen. This is justified by the almost exclusive dedication of the Portuguese apicultural sector to the production of the latter products. Indeed, the propolis' manipulation techniques are not currently the most adequate. However, since propolis has a great therapeutic potential, it is essential to study and monitor its quality.

\subsection{Antimicrobial activity}

Pathogenic microorganisms have developed multidrug resistance due to the indiscriminate use of antimicrobial drugs. This

Table 5

Minimum Inhibitory Concentration $(\mathrm{mg} / \mathrm{mL})$ for Methicillin-resistant S. aureus (MRSA) and relation between the same specie (reference culture and isolated microorganisms).

\begin{tabular}{|c|c|c|c|}
\hline Sample & Microorganism & $\begin{array}{l}\text { Mean } \pm \text { standard } \\
\text { deviation }\end{array}$ & $\begin{array}{l}\text { Microorganism's effect } \\
\text { ( } p \text {-value) }\end{array}$ \\
\hline Mirandela & $\begin{array}{l}\text { A } \\
\text { B } \\
\text { C } \\
\text { D } \\
\text { E } \\
\text { F }\end{array}$ & $\begin{array}{l}1.09 \pm 0.43 a \\
0.88 \pm 0.49 a b \\
0.65 \pm 0.20 a b \\
1.04 \pm 0.40 a \\
0.68 \pm 0.19 a b \\
0.24 \pm 0.17 b\end{array}$ & $*(0.011)$ \\
\hline Mogadouro & $\begin{array}{l}\text { A } \\
B \\
C \\
D \\
E \\
F\end{array}$ & $\begin{array}{l}1.43 \pm 0.32 a \\
0.91 \pm 0.32 a b \\
0.82 \pm 0.16 a b \\
1.04 \pm 0.40 a b \\
0.88 \pm 0.49 a b \\
0.52 \pm 0.18 b\end{array}$ & $* *(0.003)$ \\
\hline Nogueira & $\begin{array}{l}\text { A } \\
\text { B } \\
\text { C } \\
\text { D } \\
\text { E } \\
\text { F }\end{array}$ & $\begin{array}{l}0.85 \pm 0.38 \mathrm{a} \\
0.65 \pm 0.20 \mathrm{ab} \\
0.59 \pm 0.23 \mathrm{ab} \\
0.78 \pm 0.43 \mathrm{ab} \\
0.59 \pm 0.21 \mathrm{ab} \\
0.24 \pm 0.17 \mathrm{~b}\end{array}$ & NS (0.06) \\
\hline Vinhais & $\begin{array}{l}\text { A } \\
B \\
C \\
D \\
E \\
F\end{array}$ & $\begin{array}{l}0.91 \pm 0.32 a \\
0.62 \pm 0.26 a b \\
0.68 \pm 0.20 a b \\
0.85 \pm 0.38 a \\
0.72 \pm 0.35 a \\
0.24 \pm 0.16 b\end{array}$ & $* *(0.0014)$ \\
\hline
\end{tabular}

The letters a and b symbolise means that are significantly different. ${ }^{*}-p<0.05$, ${ }^{* *}$ $-p<0.01,{ }^{* * *}-p<0.001$, NS - non-significant. has led to the urgent need for new antibiotics to treat infections caused by this group of resistant bacteria. In this context, the research on the natural product with potential antimicrobial activity has mushroomed recently. Several authors have studied the antimicrobial activity of propolis. While some authors found it active only against Gram-positive bacteria and some fungi (Marcucci, 1995; Kujumgiev et al., 1999), others found also activity against Gram-negative bacteria (Dobrowolski et al., 1991). In the present study it was assessed the antimicrobial activity of four types of propolis against Methicillin-resistant S. aureus isolated from different biological fluids. Indeed, according to the Center for Disease Control and Prevention (Atlanta, USA), methicillinresistant $S$. aureus (MRSA) has been identified as an important nosocomial pathogen. It has also been reported that different strains of $S$. aureus differ in the range of diseases they can cause, including boils and pimples, wound infections, pneumonia, septicemia and food intoxication (Bayat et al., 2011).

The results for the antimicrobial activity of the samples are presented in Table 5. All the propolis samples studied presented antimicrobial activity, but this effect was dependent on the dosage and on the origin of the product. The sample from Nogueira was the most efficient in inhibiting the growth, since it was the one with lower MIC. This ranged between $0.24 \pm 0.17 \mathrm{mg} / \mathrm{mL}$ for the reference culture and $0.85 \pm 0.38 \mathrm{mg} / \mathrm{mL}$ for the strain isolated from vaginal exudates. Concerning the propolis from this origin, it weren't found significant differences between the tested microorganisms $(p=0.06)$. For the other propolis, the decreasing order of efficiency is: Vinhais $>$ Mirandela $>$ Mogadouro. In the samples from Mogadouro and Vinhais it were found highly significant differences between the effect of the propolis on the reference culture (ATCC $6538^{\mathrm{TM}}$ ) and on the $S$. aureus isolated from the vaginal exudates $(A)$. In all the cases, the reference strain was the most sensitive to the propolis action and strain $A$ the most resistant.

According to Koo et al., 2002 the antimicrobial effects of propolis are related with its flavonoids' content and consequently, vary according to the botanical origin of the product. In this study it was found that the products with higher concentration of polyphenols and flavonoids were also the ones with higher antimicrobial activity. These results are corroborated by Silva et al. (2012). Tsuchiya and Iinuma, 2000 suggest that those bioactive compounds increase the permeability of the inner bacterial membrane, nullifying its potential, decreasing the ATP production, the membrane transport and its mobility. Additionally, they inhibit the DNA gyrase which involves in the mechanism of DNA and RNA synthesis of bacteria (Mirzoeva et al., 1997).

\section{Conclusions}

Pollen analysis showed that the four propolis samples are from different vegetations: Populus sp. (Mirandela sample), Pinus sp. (Mogadouro sample), Quercus sp. (Nogueira sample) and C. sativa (Vinhais sample). The color parameter of sensory analysis allowed to distinguish the different samples because the differences show that the main vegetable origin of propolis formulation is different, 
which is supported by the sample pollinic profile. The physicochemical characterization of each sample of propolis, by using simple test procedures, showed to have important information about the samples thus allowing the identification of each sample accordingly to the geographical origin which is associated to a different pollen source, and therefore, to different sensory characteristics. By LDA it was possible to select the variables that most contribute to samples classification accordingly to pollinic profile, which in this work also corresponds to different locals of origin, and to verify that the model with four physicochemical variables has good identification performance by allowing $100 \%$ of propolis samples correctly classified. All the propolis studied presented antimicrobial activity, but this effect depended on the dosage and origin of the product. Future studies will be conducted in order to elucidate the mechanisms of action in the cell of this natural product.

\section{Conflict of Interest}

The authors declare that there are no conflicts of interest.

\section{References}

AOAC, 2005. Official Methods of Analysis, 16th ed. Association of Official Analytical Chemists, Arlington, VA, USA.

Bankova, V., 2005. Recent trends and important developments in propolis research. Evid. Based Complement. Alternat. Med. 2, 29-32.

Bankova, V.S., De Castro, S.L., Marcucci, M.C., 2000. Propolis: recent advances in chemistry and plant origin. Apidologie 31, 3-15.

Banskota, A.H., Tezuka, Y., Adnyana, I.K., Ishii, E., Midorikawa, K., Matsushige, K. Kadota, S., 2001. Hepatoprotective and anti-Helicobacter pylori activities of constituents from Brazilian propolis. Phytomedicine 8, 16-23.

Barth, O.M., 1989. O polen no mel Brasileiro. Editora Luxor, Rio de Janeiro.

Bayat, M., Zia, M., Haghi, M., Hemmatyar, G., Toghyani, M., 2011. Antibiotic resistance pattern of Escherichia coli, Staphylococcus aureus and Pseudomonas aeruginosa isolated from burnt patients in Urmia. Iran. Afr. J. Microbiol. Res. 5, 996-1000.

Bonvehi, J.S., Coll, F.V., Jordá, R.E., 1994. The composition, active components and bacteriostatic activity of propolis in dietetics. J. Am. Oil Chem. Soc. 71, 529-532

Cardoso, S., Ribeiro, M., Ferreira, I.L., Rego, A.C., 2011. Northeast Portuguese propolis protects against staurosporine and hydrogen peroxide-induced neurotoxicity in primary cortical neurons. Food Chem. Toxicol. 49, 2862-2868.

Carvalho, A.A., Finger, D., Machado, C.S., Schmidt, E.M., Costa, P.M., Alves, A.P.N.N., Morais, T.M.F., Queiroz, M.G.R., Quináia, S.P., Rosa, M.R., Santos, J.M.T., Pessoa, C. Moraes, M.O., Costa-Lotufo, L., Sawaya, A.C.H.F., Eberlin, M.N., Torres, Y.R., 2011. In vivo antitumoural activity and composition of an oil extract of Brazilian propolis. Food Chem. 126, 1239-1245.

Choi, Y.M., Noh, D.O., Cho, S.Y., Suh, H.J., Kim, K.M., Kim, J.M., 2006. Antioxidant and antimicrobial activities of propolis from several regions of Korea. LWT 39, 756761.

Dobrowolski, J.W., Vohora, S.B., Sharma, K., Shah, S.A., Naqvi, S.A.H., Dandlya, P.C., 1991. Antibacterial, antifungal, antiamoebic, anti-inflammatory and antipyretic studies on propolis bee products. J. Ethnopharm. 35, 77-82.

Falcão, S.I., Vilas-Boas, M., Estevinho, L.M., Barros, C., Domingues, M.R., Cardoso, S 2010. Phenolic characterization of Northeast Portuguese propolis: usual and unusual compounds. Anal. Bioanal. Chem. 396, 887-897.

Feldsine, P.T., Lienau, A.H., Roa, N.H., Green, S.T., 2005. Enumeration of total coliforms and E. coli in foods by the sim plate coliform and E. coli color indicator method and conventional culture methods: collaborative study. J. AOAC Int. 88, 5.

Fontana, J.D., Adelmann, J., Passos, M., Maraschin, M., Lacerda, C.A., Lanças, F.M., 2004. Propolis: chemical micro-heterogeneity and bioactivity. Environ. Microbiol. Methods Prot. 16, 203-218.

Gekker, G., Hu, S., Spivak, M., Lokensgard, J.R., Peterson, P.K., 2005. Anti-HIV-1 activity of propolis in $\mathrm{CD}^{4+}$ lymphocyte and microglial cell cultures. J. Ethnopharmacol. 102, 158-163.

Gomes, S., Dias, L., Moreira, L., Rodrigues, P., Estevinho, L.M., 2010. Physicochemical, microbiological and antimicrobial properties of commercial honeys from Portugal. Food Chem. Toxicol. 48, 544-548.

Horner, K.L., Anagnostopoulos, G.D., 1973. Combined effects of water activity, pH and temperature on the growth and spoilage potential of fungi. J. Appl. Microbiol. 36, 427-436.
ISO 15213, 2003. Microbiology of Food and Animal Feeding Stuffs - Horizontal method for the enumeration of sulfite-reducing bacteria growing under anaerobic conditions. International Standards Organization, Switzerland.

ISO 21527-2, 2008. Microbiology of Food and Animal Feeding Stuffs - Horizontal Method for the Enumeration of Yeasts and Moulds - Part 2: Colony Count Technique in Products with Water Activity Less Than or Equal to 0.95 . International Standards Organization, Switzerland.

Kilic, A., Baysallar, M., Besirbellioglu, B., Salih, B., Sarkun, K., Tanyuksel, M., 2005. In vitro antimicrobial activity of propolis against methicillin-resistant Staphylococcus aureus and vancomycin-resistant Enterococcus facium. Ann. Microbiol. 55 (2), 113-117.

Koo, H., Rosalen, P.L., Cury, J.A., Park, Y.K., Bowen, E.H., 2002. Effects of compounds found in propolis in Streptococcus mutans growth and glusyltransferaseactivity. Antimicrob. Agents Chemother. 46, 1302-1309.

Krol, W., Czuba, Z., Scheller, S., Gabrys, J., Grabiec, S., Shani, J., 1990. Anti-oxidant property of ethanolic extract of propolis (EEP) as evaluated by inhibiting the chemiluminescence oxidation of luminol. Biochem. Int. 21, 593-597.

Kujumgiev, A., Tsvetkova, I., Serkedjieva, Y., Bankova, V., Christov, R., Popov, S., 1999. Antibacterial, antifungal and antiviral activity of propolis of different geographic origin. J. Ethnopharmacol. 64, 235-240.

Kumazawa, S., Hamasaka, T., Nakayama, T., 2004. Antioxidant activity of propolis of various geographic origins. Food Chem. 84, 329-339.

Libério, S.A., Pereira, A.L., Araújo, M.J., Dutra, R.P., Nascimento, F.R., Monteiro-Neto, V., Ribeiro, M.N., Gonçalves, A.G., Guerra, R.N., 2009. The potential use of propolis as a cariostatic agent and its actions on mutans group streptococci. J. Ethnopharmacol. 125, 1-9.

Marcucci, M.C., 1995. Propolis: chemical composition, biological properties and therapeutical activity. Apidologie 26, 83-99.

Mirzoeva, O.K., Grishanin, R.N., Calder, P.C., 1997. Antimicrobial action of propolis and some of its components: the effects on growth, membrane potential and motility of bacteria. Microbiol. Res. 152, 239-246.

Moreira, L., Dias, L.G., Pereira, J.A., Estevinho, L., 2008. Antioxidant properties, total phenols and pollen analysis of propolis samples from Portugal. Food Chem. Toxicol. 46, 3482-3485.

Negri, G., Marcucci, M.C., Salatino, A., Salatino, M.L., 1998. Hydrocarbons and monoesters of propolis waxes from Brazil. Apidologie 29, 305-314.

NP 1309, 1976 (Ed. 1) - Mel - Determinação da acidez.

NP 3788, 2002. Microbiologia Alimentar - Regras gerais para a contagem de microrganismos a $30^{\circ} \mathrm{C}$. Instituto Português da Qualidade, Portugal.

NP 4400-1, 2002. Microbiologia alimentar: Norma portuguesa: regras gerais para contagem de Estafilococos coagulase positiva: Parte 1: Técnica com confirmação de colónias (Método corrente). Instituto Português da Qualidade, Portugal.

Pastor, C., Sánchez-González, L., Cháfer, M., Chiralt, A., González-Martínez, C., 2010. Physical and antifungal properties of hydroxypropylmethylcellulose based films containing propolis as affected by moisture content. Carbohydr. Polym. 82, 1174-1183.

Paulino, N., Abreu, S.R.L., Uto, Y., Koyama, D., Nagasawa, H., Hori, H., Dirsch, V.M., Vollmar, A.M., Scremin, A., Bretz, W.A., 2008. Anti-inflammatory effects of a bioavailable compound, Artepillin C in Brazilian propolis. Eur. J. Pharmacol. 587, 296-301.

Pereira, A.S., Seixas, F.R.M.S., Neto, F.R.A., 2002. 100 Years of research and future perspectives. Quim. Nova 25, 321-326.

Popova, M., Bankova, V., Butovska, D., Petkov, V., Nikolova-Damyanova, B., Sabatini, A., Marcazzan, G., Bogdanov, S., 2004. Validated methods for the quantification of biologically active constituents of poplar-type propolis. Phytochem. Anal. 15, 235-240.

Sarker, S.D., Nahar, L., Kumarasamy, Y., 2007. Microtiter plate-based antibacterial assay incorporating resazurin as an indicator of cell growth, and its application in the in vitro antibacterial screening of phytochemicals. Methods 42, 321-324.

Salonem, A., Saarnio, S., Julkunen-Tiitto, R., 2012. Phenolic compounds of propolis from Boreal Coniferous zone. J. Apic. Sci. 56, 13-22.

Silva, J.C., Rodrigues, S., Feás, X., Estevinho, L.M., 2012. Antimicrobial activity, phenolic profile and role in the inflammation of propolis. Food Chem. Toxicol. 50, 1790-1795.

Sousa, J.P.B., Niege, A.J.C., Furtado, N.A.J.C., Jorge, R., Soares, A.E.E., Bastos, J.K., 2007. Perfis físico-químico e cromatográfico de amostras de própolis produzidas nas microrregiões de Franca (SP) e Passos (MG), Brasil. Braz. J. Pharmacogn. 17, 8393.

Tikhonov, A.I., Salo, D.P., Pryakhin, O.R., Gritsenko, V.I., 1978. Standardization of propolis. Pharm. Chem. 3, 1694-1699.

Tsuchiya, H., Iinuma, M., 2000. Reduction of membrane fluidity by antibacterial sophoraflavone G isolated from Sophora exigua. Phytomedicine 7, 161-165.

Valente, M.J., Baltazar, A.F., Henrique, R., Estevinho, L.M., Carvalho, M., 2011. Biological activities of Portuguese propolis: protection against free radicalinduced erythrocyte damage and inhibition of human renal cancer cell growth in vitro. Food Chem. Toxicol. 49, 86-92. 